\title{
On Studying the Mix of Relationships amongst the Challenges behind Successful Adoption of Microfinance in India
}

\author{
Lokik Aggarwal \\ Recventures Education Services \\ Private Limited \\ Delhi, India
}

\author{
Bina Dharilal Aggarwal \\ Recventures Education Services \\ Private Limited \\ Delhi, India
}

\author{
Remica Aggarwal \\ Recventures Education Services \\ Private Limited \\ Delhi, India
}

\begin{abstract}
Especially amongst the developing nations, there is a general consensus attached to microfinance and microcredit about the tremendous potential it has to alleviate poverty and build socio-economic empowerment of its beneficiaries. However, this potential of microfinance also faces a lot of challenges and a lot of inhibiting factors in and around the beneficiaries which reduce the socio-economic empowerment to an extent that the microfinance programme might require changes to be more effective. This study elaborates on various success factors and inhibitors of micro finance in India and further studies the inter-relationship amongst them using ISM methodology. The factors can further be studied as in context of Finance portfolio optimization.
\end{abstract}

\section{Keywords}

Micro- finance ; Inhibiting factors ; ISM Methodology

\section{INTRODUCTION}

Microfinance is one of most visible innovations in antipoverty policy as it helps in creating sustained impact by educating recipients on how to create their own businesses and how to properly manage and grow their money. It has been particularly useful in poverty stricken areas in providing long term financial independence. Microfinance institutions (MFIs) have created a massive social infrastructure uniquely positioned to reach millions of clients on a regular basis.

Pioneering of modern microfinance is usually credited to Dr. Mohammad Yunus, who began experimenting with lending to poor women within the village of Jobra, Bangladesh throughout his tenure as a professor of economics at Chittagong University during 1970s. As a result, he started Grameen bank in 1976 . He and the bank were jointly awarded with Nobel peace prize in $2006{ }^{1}$. Additionally the success of Grameen Bank has aroused the formation of different many microfinance institutions like ASA, BRAC and PROSHIKA .

\subsection{Microfinance and MFIs Indian scenario [1-4]}

In 1973, the Self-employed Women's Association (SEWA) of Gujarat (in India) formed a bank, named as Mahila SEWA Cooperative Bank, to access bound financial services easily. Nearly four thousand women contributed their share capital to create the bank. In India, a range of institutions within the public sector as well as the private sector, offers microfinance services which can be broadly categorized into formal and semi-formal institutions. Whereas the formal institutions contains apex development financial institutions, commercial banks, regional rural banks and cooperative banks, semi- formal institutions undertake microfinance services as their main activity. They are therefore usually named as microfinance establishments (MFIs). Some of the Indian MFIzs are National Bank for Agriculture and Rural Development (NABARD), Small Industries Development Bank of India (SIDBI) and Rashtriya Mahila Kosh (RMK). At the retail level, commercial banks, regional rural banks and cooperative banks provides microfinance services. Now days, there are about 60,000 retail credit outlets of the formal banking sectors in the geographical region comprising 12,000 branches of district level cooperative banks, over 14,000 branches of the Regional Rural Banks (RRBs) and over 30,000 rural and semi-urban branches of commercial banks besides over 90,000 cooperatives credit societies at the village level.

\subsection{Microfinance and Women} Empowerment: Evidence from India [516]

- Out of the world's total population under poverty, $70 \%$ are women. Gujarat is considered to be a huge potential market for Microfinance. The SHGs in Gujarat are popularly termed as Sakhi Mandals. Ranjula Bali Swain [8] investigates the positive impact of microfinance on women's empowerment. The study by [9], presented strong evidence of positive impact of SHGs on the socio-economic characteristics of the members.

- Women empowerment through self - help groups [11], revealed that the SHGs have had greater impact on both economic and social aspects of the beneficiaries.

- Das [16] highlighted in his study the role tribal women play in the co-management of their natural, social, economic resources and agricultural development including crop production, livestock production, etc. [10], revealed that the women had limited control over money and money management within their households, whereas men were communicative about finances but unwilling to discuss with wives.

- Swain [8], in her study, has shown a definite economic impact on households, with increase in income and decline in vulnerability.

- Debadutta Kumar Panda [9] studied the impact of participation in microfinance, in 3 states Orissa, Jharkhand and Chhattisgarh of India and concluded 
that there is a positive impact of self-help groupbased microfinance intervention in the income, assets position, savings, employment, literacy, consumption and migration reduction.

- Lakshmi R and Vadivalagan G [11], revealed that the SHGs have greater impact on both economic and social aspects of the beneficiaries.

- Das[16] focused on the constraints in empowerment of Karbi women in Karbi Anglong district of Assam. Sara Noreen [14] studied women empowerment by using five indicators: child health, education, selection of spouse of children, purchase of basic goods and decision about use of loan. Aruna M and Jyothirmayi R.[15] studied the role of microfinance in empowering women with SHG Bank linkage programme and concludes that microfinance sector should extend its hand in the interest of the poor women who definitely need full range of financial services, $x$.

In view of above literature, present research has following objectives :

- To explore various challenges associated with micro-finance in India .

- To establish the inter-relationships amongst them using ISM methodology.

The paper is arranged as follows : Section 2 is the literature review on the history of micro-finance in India and abroad. Section 3 describes the various challenges and benefactors associated with micro-finance in India. Section 4 presents the ISM methodology and case example is present in section 5 .

\section{LITERATURE REVIEW ON CHALLENGES AND SUCCESS FACTORS OF MICRO FINANCE IN INDIA}

\subsection{Challenges of Micro-Finance in India [6-16]}

2.1.1 Financial illiteracy [FILL]: One of the foremost challenge in India towards the expansion of the microfinance sector is the financial illiteracy of the people. This makes it tough in creating awareness of microfinance and even harder to serve them as microfinance clients.

2.1.2 Client Retention [CR]: Client retention is a problem that makes a haul in growing the MFIs. There is concerning 28 th client retention within the MFIs.

2.1.3 Loan Default [LD]: Loan default is a problem that makes a haul in growth and enlargement of the organization because around 73 loan defaults are identified in MFIs.

2.1.4 Language Barrier [LB]: Language barrier makes communication with the clients (verbal and written) is a difficulty that makes a haul in growth and enlargement of the organization because around 54 language barrier has been identified in MFIs.

2.1.5 Late Payments [LP]: Late payments are a problem that makes a haul in growth and enlargement of the organization because late payments are around 70th in MFIs.

2.1.6 Geographic Factors [GF]: The Geographic factors create it troublesome to communicate with clients of far-flung areas that produce a haul in growth and enlargement of the organization.

2.1.7 Debt Management [DM]: One of the biggest challenge is the lack of education and knowledge regarding debt management.

2.1.8 Negligence of Urban Poor [NUP]: It has been noted that MFIs pay more attention to rural areas and mostly neglect the urban poor. Out of more than 800 MFIs across India, only six are presently focusing their attention on the urban poor.

2.1.9 High Interest Rate [HIR] : MFIs are charging very high interest which the poor find troublesome to pay.

\subsection{Benefactors or success factors}

The following are some actions to overcome the challenges faced by MFIs in providing microfinance services to possess a sustainable development.

2.1.10 Transparency of Interest Rates [TOR] : MFIs are using different patterns of charging interest rates and some are charging extra charges and interest free deposits. All this make the pricing very confusing and therefore the borrower feels incompetent in terms of bargaining power.

2.1.11 Proper Regulation [PR] : As the sector completes nearly two decades of age with a high growth trajectory, an enabling regulatory atmosphere is required that protects interest of stakeholders as well as promotes growth.

2.1.12 Encourages Rural Penetration [ERP]:
[E Encouraging MFIs for opening new branches in areas of low microfinance penetration by providing financial help will increase the outreach of the microfinance within the state and check multiple lending. This will also increase rural penetration of microfinance within the state.

2.1.13 Field supervision [FS] : In addition to proper regulation of the microfinance sector, field visits can be adopted as a medium for monitoring the conditions on ground and initiating corrective action if required. This will keep a watch on the performance of ground employees of various MFIs and their recovery practices.

2.1.14 Complete range of products [CRP]: MFIs should give complete range of products including credit, savings, remittance, financial recommendation and also nonfinancial services like training and support.

\section{INTERPRETIVE STRUCTURAL MODELLING METHODOLOGY}

Suggested by Warfield [17], ISM works with the following steps: It starts with identifying the relevant elements and pairwise establishing the contextual relationship amongst them. Thereafter, a structural self-interaction matrix (SSIM) may be developed between two variables i.e. $i$ and $j$ establishing a "Lead to" relationship between criteria. Four symbols viz. V, A , $\mathrm{X} \& \mathrm{O}$ are used for establishing the relationships. After that, a level partition matrix can be obtained based on establishing the precedence relationships and arranging the 
elements in a topological order. A Mic-Mac analysis is performed categorizing the variables in to autonomous, dependent, driver and linkage category. Finally, a diagraph can be obtained.

\section{CASE EXAMPLE}

The 09 barriers viz. Financial illiteracy [FILL]; Poor Client Retention [PCR]; Loan Default [LD]; Language Barrier [LB]; Late Payments [LP]; Geographic Factors [GF] ; Poor Debt Management [PDM]; Negligence of Urban Poor [NUP]; High Interest Rate [HIR] described in section 2.1 and 05 success factors viz. Transparency of Interest Rates [TOR]; Proper Regulation [PR]; Encourages Rural Penetration [ERP]; Field supervision [FS] and Complete range of products [CRP] described in section 2.2 has been studied further to determine the possible inter-relationships amongst them using ISM methodology .

\subsection{Construction of Structural self- interaction Matrix (SSIM)}

This matrix gives the pair-wise relationship between two variables i.e. $i$ and $j$ based on VAXO. SSIM has been presented below in Fig 1.

\subsection{Construction of Initial Reachability Matrix and final reachability matrix}

The SSIM has been converted in to a binary matrix called the initial reachability matrix shown in fig. 2 by substituting $\mathrm{V}, \mathrm{A}$, $\mathrm{X}, \mathrm{O}$ by 1 or 0 as per the case. After incorporating the transitivity, the final reachability matrix is shown below in the Fig 3.

Fig 1: SSIM matrix for pair wise relationship amongst barriers

\begin{tabular}{|c|c|c|c|c|c|c|c|c|c|c|}
\hline S. No. & Barriers & 1 & 2 & 3 & 4 & 5 & 6 & 7 & 8 & 9 \\
\hline & & FILL & PCR & LD & LB & LP & GF & PDM & NUP & HIR \\
\hline 1 & FILL & & V & V & A & V & A & V & V & V \\
\hline 2 & PCR & & & V & A & V & A & V & V & V \\
\hline 3 & LD & & & & A & V & A & A & V & V \\
\hline 4 & LB & & & & & V & V & V & V & V \\
\hline 5 & LP & & & & & & A & A & A & A \\
\hline 6 & GF & & & & & & & V & V & V \\
\hline 7 & PDM & & & & & & & & A & A \\
\hline 8 & NUP & & & & & & & & & A \\
\hline 9 & HIR & & & & & & & & & \\
\hline
\end{tabular}

Fig 2: Initial reachability matrix

\begin{tabular}{|c|c|c|c|c|c|c|c|c|c|c|}
\hline S. No. & Barriers & 1 & 2 & 3 & 4 & 5 & 6 & 7 & 8 & 9 \\
\hline & & FILL & PCR & LD & LB & LP & GF & PDM & NUP & HIR \\
\hline 1 & FILL & 1 & 1 & 1 & 0 & 1 & 0 & 1 & 1 & 1 \\
\hline 2 & PCR & 0 & 1 & 1 & 0 & 1 & 0 & 1 & 1 & 1 \\
\hline 3 & LD & 0 & 0 & 1 & 0 & 1 & 0 & 0 & 1 & 1 \\
\hline 4 & LB & 1 & 1 & 1 & 1 & 1 & 1 & 1 & 1 & 1 \\
\hline 5 & LP & 0 & 0 & 0 & 0 & 1 & 0 & 0 & 0 & 0 \\
\hline 6 & GF & 1 & 1 & 1 & 0 & 1 & 1 & 1 & 1 & 1 \\
\hline 7 & PDM & 0 & 0 & 1 & 0 & 1 & 0 & 1 & 0 & 0 \\
\hline 8 & NUP & 0 & 0 & 0 & 0 & 1 & 0 & 1 & 1 & 0 \\
\hline 9 & HIR & 0 & 0 & 0 & 0 & 1 & 0 & 1 & 1 & 1 \\
\hline
\end{tabular}

Fig 3 : Final reachability matrix

\begin{tabular}{|c|c|c|c|c|c|c|c|c|c|c|c|}
\hline S. No. & Barriers & 1 & 2 & 3 & 4 & 5 & 6 & 7 & 8 & 9 & D.P \\
\hline & & FILL & PCR & LD & LB & LP & GF & PDM & NUP & HIR & \\
\hline 1 & FILL & 1 & 1 & 1 & 0 & 1 & 0 & 1 & 1 & 1 & 7 \\
\hline 2 & PCR & 0 & 1 & 1 & 0 & 1 & 0 & 1 & 1 & 1 & 6 \\
\hline 3 & LD & 0 & 0 & 1 & 0 & 1 & 0 & 1 & 1 & 1 & 4 \\
\hline
\end{tabular}




\begin{tabular}{|l|c|c|c|c|c|c|c|c|c|c|c|}
\hline 4 & LB & 1 & 1 & 1 & 1 & 1 & 1 & 1 & 1 & 1 & 9 \\
\hline 5 & LP & 0 & 0 & 0 & 0 & 1 & 0 & 0 & 0 & 0 & 1 \\
\hline 6 & GF & 1 & 1 & 1 & 0 & 1 & 1 & 1 & 1 & 1 & 8 \\
\hline 7 & PDM & 0 & 0 & 1 & 0 & 1 & 0 & 1 & 0 & 0 & 3 \\
\hline 8 & NUP & 0 & 0 & 1 & 0 & 1 & 0 & 1 & 1 & 0 & 3 \\
\hline 9 & HIR & 0 & 0 & 1 & 0 & 1 & 0 & 1 & 1 & 1 & 4 \\
& & & & & & & & & & & \\
\hline & De.P & 3 & 4 & 8 & 1 & 9 & 2 & 8 & 7 & 6 & \\
\hline
\end{tabular}

D.P : Driving power ; De.P : Dependence power

\subsection{Level Partition}

From the final reachability matrix, reachability and final antecedent set for each factor are found. The elements for which the reachability and intersection sets are same are the top-level element in the ISM hierarchy. After the identification of top level element, it is separated out from the other elements and the process continues for next level of elements. Reachability set, antecedent set, intersection set along with different level for elements have been shown below in table 1 .

Table 1: Iteration I

\begin{tabular}{|c|c|c|c|c|}
\hline $\begin{array}{c}\text { S.No } \\
\text {. }\end{array}$ & $\begin{array}{c}\text { Reachability } \\
\text { set }\end{array}$ & Antecedent set & $\begin{array}{c}\text { Intersectio } \\
\text { n set }\end{array}$ & $\begin{array}{c}\text { Lev } \\
\text { el }\end{array}$ \\
\hline 1. & 5 & $\begin{array}{c}1,2,3,4,5,6,7,8 \\
9\end{array}$ & 5 & \multirow{7}{*}{ I } \\
\hline 2. & $5,7,3$ & $1,2,3,4,6,7,8,9$ & 7,3 & \\
\hline 3. & $3,5,7,8$ & $1,2,3,4,6,8,9$ & 8 & \\
\hline 4. & $3,5,7,8,9$ & $1,2,3,4,6,9$ & 3,9 & \\
\hline 5. & $2,3,5,7,8,9$ & $1,2,4,6,9$ & 2,9 & \\
\hline 6. & $1,2,3,5,7,8,9$ & $1,4,6$ & 1 & \\
\hline 7. & $1,2,3,4,5,7,8,9$ & 4 & 4 & \\
\hline
\end{tabular}

Table 2: Iteration II

\begin{tabular}{|c|c|c|c|c|}
\hline S. No. & $\begin{array}{c}\text { Reachability } \\
\text { set }\end{array}$ & Antecedent set & $\begin{array}{c}\text { Intersectio } \\
\text { n set }\end{array}$ & $\begin{array}{c}\text { Lev } \\
\text { el }\end{array}$ \\
\hline 2. & $\mathbf{7 , 3}$ & $1,2,3,4,6,7,8,9$ & 7,3 & \\
\hline 3. & $3,7,8$ & $1,2,3,4,6,8,9$ & 8 & \\
\hline 4. & $3,7,8,9$ & $1,2,3,4,6,9$ & 3,9 & \multirow{2}{*}{ II } \\
\cline { 1 - 4 } 5. & $2,3,7,8,9$ & $1,2,4,6,9$ & 2,9 & \\
\cline { 1 - 4 }. & $1,2,3,7,8,9$ & $1,4,6$ & 1 & \\
\hline 7. & $1,2,3,4,7,8,9$ & 4 & 4 & \\
\hline
\end{tabular}

Table 3: Iteration III

\begin{tabular}{|c|c|c|c|c|}
\hline $\begin{array}{c}\text { S.No } \\
\cdot\end{array}$ & $\begin{array}{c}\text { Reachability } \\
\text { set }\end{array}$ & Antecedent set & $\begin{array}{c}\text { Intersectio } \\
\text { n set }\end{array}$ & $\begin{array}{c}\text { Lev } \\
\text { el }\end{array}$ \\
\hline 3. & $\mathbf{8}$ & $1,2,4,6,8,9$ & 8 & \\
\hline 4. & $7,8,9$ & $1,2,4,6,9$ & 9 & \\
\hline
\end{tabular}

\begin{tabular}{|c|c|c|c|c|}
\hline 5. & $2,7,8,9$ & $1,2,4,6,9$ & 2,9 & \multirow{2}{*}{ III } \\
\cline { 1 - 4 } & $1,2,7,8,9$ & $1,4,6$ & 1 & \\
\hline 7. & $1,2,4,7,8,9$ & 4 & 4 & \\
\hline
\end{tabular}

Table 4: Iteration IV

\begin{tabular}{|c|c|c|c|c|}
\hline $\begin{array}{c}\text { S.No } \\
\cdot\end{array}$ & $\begin{array}{c}\text { Reachability } \\
\text { set }\end{array}$ & Antecedent set & $\begin{array}{c}\text { Intersectio } \\
\text { n set }\end{array}$ & $\begin{array}{c}\text { Lev } \\
\text { el }\end{array}$ \\
\hline 4. & $\mathbf{9}$ & $1,2,4,6,9$ & 9 & \multirow{2}{*}{ IV } \\
\cline { 1 - 4 } 5. & $2,7,9$ & $1,2,4,6,9$ & 2,9 & \\
\cline { 1 - 2 } 6. & $1,2,7,9$ & $1,4,6$ & 1 & \\
\hline 7. & $1,2,4,7,9$ & 4 & 4 & \\
\hline
\end{tabular}

Table 5: Iteration V

\begin{tabular}{|c|c|c|c|c|}
\hline $\begin{array}{c}\text { S.No } \\
\cdot\end{array}$ & $\begin{array}{c}\text { Reachability } \\
\text { set }\end{array}$ & Antecedent set & $\begin{array}{c}\text { Intersectio } \\
\text { n set }\end{array}$ & $\begin{array}{c}\text { Lev } \\
\text { el }\end{array}$ \\
\hline 5. & $\mathbf{2}$ & $1,2,4,6$ & 2 & \\
\cline { 1 - 4 }. & 1,2 & $1,4,6$ & 1 & \multirow{2}{*}{ V } \\
\hline 7. & $1,2,4$ & 4 & 4 & \\
\hline
\end{tabular}

Table 6: Iteration VI

\begin{tabular}{|c|c|c|c|c|}
\hline $\begin{array}{c}\text { S.No } \\
\cdot\end{array}$ & $\begin{array}{c}\text { Reachability } \\
\text { set }\end{array}$ & Antecedent set & $\begin{array}{c}\text { Intersectio } \\
\text { n set }\end{array}$ & $\begin{array}{c}\text { Lev } \\
\text { el }\end{array}$ \\
\hline 6. & $\mathbf{1}$ & $1,4,6$ & 1 & \\
\cline { 1 - 4 } & 1,4 & 4 & 4 & VI \\
\hline
\end{tabular}

Table 7: Iteration VII

\begin{tabular}{|c|c|c|c|c|}
\hline $\begin{array}{c}\text { S.No } \\
\cdot\end{array}$ & $\begin{array}{c}\text { Reachability } \\
\text { set }\end{array}$ & Antecedent set & $\begin{array}{c}\text { Intersectio } \\
\text { n set }\end{array}$ & $\begin{array}{c}\text { Lev } \\
\text { el }\end{array}$ \\
\hline 7. & $\mathbf{4}$ & 4 & 4 & VII \\
\hline
\end{tabular}




\subsection{ISM Diagraph}

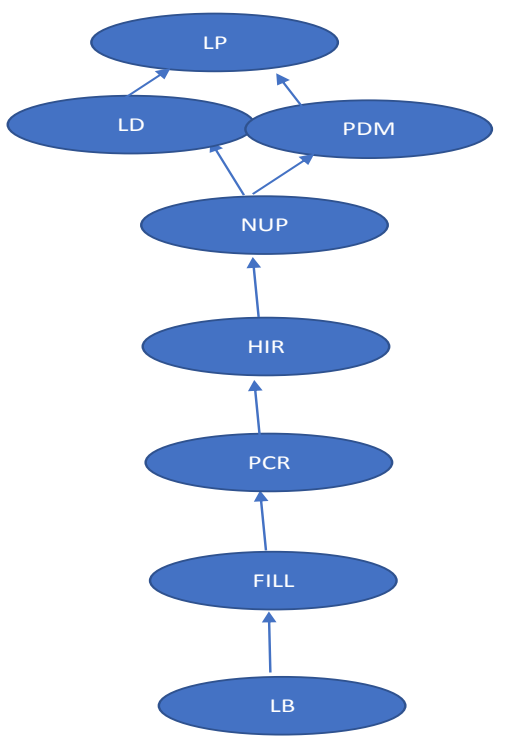

Fig 5 : ISM Diagraph

\section{CONCLUSIONS}

Present research tries to establish the inter-relationships amongst the various barriers and success factors for the growth /decline of micro-financing and foreign direct investment (FDI) in India using ISM methodology .

\section{FUTURE DIRECTIONS}

The factors and the related challenges can further be studied as part of financial / portfolio optimization modelling .

\section{ACKNOWLEDGEMENTS}

Co-author Remica Aggarwal extend her sincere thanks to Prof. S.P. Singh, DMS , IIT Delhi for disseminating knowledge about ISM Methodology .

\section{APPENDix}

\section{Benefits of Microfinance in Economic Development}

\section{a.1 Poverty Alleviation}

To eradicate poverty most of the nations have been pursuing various policies and programs. Among these most effective policy adopted by the low income countries in the world is microfinance because it has been found an effective tool for lifting the poor by providing them financial services to start or expand a small business that enables them to break out of poverty.

\section{a.2 Financial Inclusion}

Microfinance has been recognized as an important tool in connectivity the unbanked population to mainstream institutional banking services. It has contributed to reduce their dependency on informal money lenders and noninstitutional sources.

\section{a.3 Development of Skills}

Microfinance has helped in identifying the potential rural entrepreneurs. SHGs encourage its members to set up their businesses jointly or individually. They receive training from their supporting institutions and learn leadership qualities. Thus, microfinance helps indirectly in the Development of Skills.

\section{a.4 Global Poverty}

As many of these communities started growing, the local economies are started flourishing. The gross domestic product of the country started increasing and gap between the poorer and wealthiest people has also decreased.

\section{a.5 Financial Stability}

Microfinance has also played a greatest in providing financial stability to people which contributed to local economies in substantial extent. Small loans have offered opportunities to earn extra income, so that people can pay for their extreme necessities.

\section{a.6 Credit to Rural Poor}

Micro-financing has improved the drawback of lack of institutionalized credit to the doorstep of poor and have made them economically and socially sound.

\section{a.7 Economic Growth}

Finance plays a key role in stimulating sustainable economic growth. Due to microfinance, production of goods and services increases which increases GDP and contributes to economic growth of the country.

\section{a.8 Mobilization of Savings}

The financial resources generated through savings and micro credit obtained from banks are utilized to provide loans and advances to its members. Thus microfinance helps in mobilization of savings.

\section{a.9 Mutual Help and Co-operation}

Microfinance promotes mutual help and co-operation among members thereby promoting the economic interest and helps in achieving socio-economic transition.

\section{a.10 Social Welfare}

Micro finance leads to social welfare or betterment of society due to increase in level of income.

\section{a.11 Rural India and Microfinance}

Micro finance is expected to play a significant role in poverty alleviation and development. therefore it is required to share experiences and materials which will help in providing knowledge and guidelines to strengthen and expand micro finance programs.

\section{a.12 Women Empowerment}

SHGs has proved to be strategic tool for organizing women in groups and promoting their saving habits to gain greater access to financial and economic resources.

\section{REFERENCES}

[1] NABARD 2011. Status of microfinance in India 20102011. Annual Report of National Bank for Agriculture and Rural Development.

[2] Mahanta . 2012. Status of microfinance in India- A review, International Journal of Marketing, Financial Services \& Management Research, ISSN 2277 3622, $1(11)$.

[3] Bhatia, A., Malik, D. and Sindhi, V. 2013. Microfinance in India and its impact on Poverty Alleviation. Asian Journal of Research in Business Economics and Management, 3(2), 57-67.

[4] RBI 2011. Report on trend and progress of Banking in India 2010-11. Annual Report submitted to Government of India by Reserve Bank of India.

[5] Imhanlahimi, J. and Idolar, E.J. 2010. Poverty alleviation through micro financing in Nigeria: Prospects and 
Challenges. Journal of financial management and Analysis, 23(1), 66-82.

[6] Chakrabarti, R. 2004.The Indian microfinance experience-Accomplishment and Challenges.

[7] Kodamarty, M. Microfinance and Women Empowerment: Self Perception of Beneficiaries - A Study With Reference to Gandhinagar District of Gujarat, 5(1), ISSN 2277-8179.

[8] Swain, R.B. and Wallentin , F.Y. 2014. The Impact of Microfinance on Factors Empowering Women: Differences in Regional and Delivery Mechanisms in India's SHG Programme, Journal of Development Studies, DOI: 10.1080/00220388.2016.1205732

[9] Panda , D.K. 2009. Assessing the impact of participation in women self-help group-based microfinance: Nonexperimental evidences from rural households in India, International Journal of Rural Management 5 (2), 197 215 .

[10] Bijli, K.H. 2012. Financial Literacy: An Essential Tool for Empowerment of Women through Micro-finance. Stud Home Com Sci, 6(2): 77-85.

[11] Lakshmi.R \& Vadivalagan.G., 2014. Impact of SHGs on Empowerment of Women: A study in Dharmapuri District, Journal of Management and Science, Tamil
Nadu, 43-54.

[12] Afrin, S, Islam, N, Ahmed, S.U. 2010. Microcredit \& rural women entrepreneurship Bangladesh: A multivariate model development in

[13] Das, S.K. 2011.Women Empowerment and Self Help Group: An Analytical study of Constraints in Karbi Anglong District of Assam. Journal of North East India

[14] Sara, N. 2011. Role of microfinance in empowerment of female population of Bahawalpur district Conference on Economics and Finance Research, 2011. vol.4

[15] Aruna, M. and Jyothirmayi, R. 2011.The Role of microfinance in Women Empowerment: A study of the SHG bank. linkage program in Hyderabad. Internationally Indexed Journal, www.scholarshub.net, 2(4).

[16] Das, 2012. Socio-economic empowerment of women through SHG banking linking programme :A boon for development . International journal of management and business studies . 2(1).

[17] Warfield, J.N. 1974. Developing interconnection matrices in structural modelling, in the proceedings of IEEE Transactions on System, Man, and Cybernetics, SMC, 4 (1), 81-87. 